\title{
COVID-19: Cosmopolitanism's Criticism and Proposals
}

\author{
Mahbi Maulaya ${ }^{1}$ and Nanda Blestri Jasuma ${ }^{2}$
}

Received: 15 April 2021 | Accepted: 24 June 2021 | Published: 2 July 2021

\begin{abstract}
Covid-19 merits a scientific examination from cosmopolitanism, a widely acknowledged, global-nuanced thought. During the pandemic, strong stances of nationalism and xenophobia have been taken, leaving little room for global cooperation in countering the virus, and recognition of human rights has ebbed. Since this reality is opposed to its ideational and normative essence, cosmopolitanism offers its criticisms and proposals. By diving into a cosmopolitan way of thinking, this study criticises the rise of 'health nationalism' in state policies as well as the xenophobia manifested through the blaming of people of Asianparticularly Chinese-heritage for the viral outbreak. Regarding its proposals, cosmopolitanism offers two suggestions: 1) international society must opt to endorse global integration through multilateralism, and 2.) countries should avoid exclusionary health programmes and commit to solidarity-based countermeasures. The underlying arguments of this study are backed by the application of library research and qualitative methods.
\end{abstract}

Keywords: cosmopolitanism; covid-19; global integration; nationalism; xenophobia.

\section{Introduction}

At the end of January 2020, the World Health Organisation (WHO) officially declared COVID-19 a global pandemic, a 'public health emergency of international concern' (Schumaker, 2020). As of 28 April 2020, more than 2.8 million cases of COVID-19-including 198,000 deaths-have been reported in 213 countries worldwide.

\footnotetext{
${ }^{1}$ Department of International Relations, Universitas Muhammadiyah Yogyakarta. Email: maulayamahbi@gmail.com

${ }^{2}$ Department of International Relations, Universitas Muhammadiyah Yogyakarta. Email: nanda.blestri.fisip18@mail.umy.ac.id
} 
Figure 1.

Geographical distribution of COVID-19 cases, worldwide

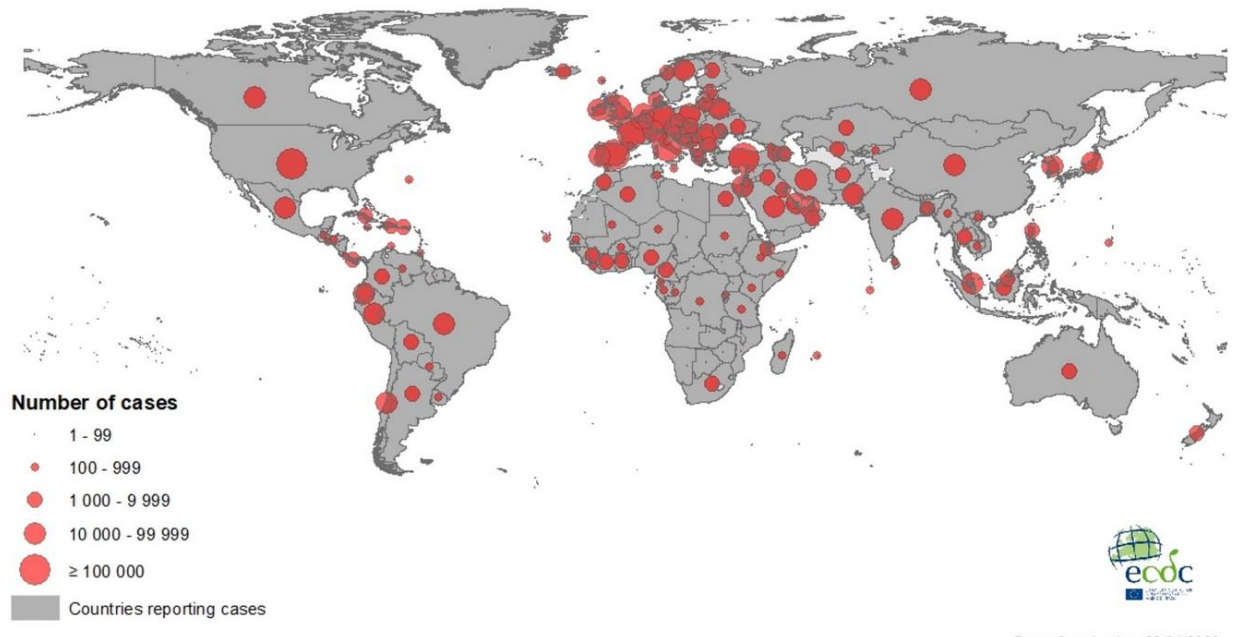

Date of production: 28/04/2020

Source: European Centre for Disease Prevention and Control

(https://www.ecdc.europa.eu/en/geographical-distribution-2019-ncov-cases)

The COVID-19 outbreak has spread more rapidly and infected more people than the previous two pandemics combined; only 8,000 cases of SARS were reported, with 774 deaths, while 2,519 cases of MERS were reported, with 866 deaths. Despite its prevalence, COVID-19 has a quite low fatality rate, estimated at only $2 \%$ (Wang et al. 2020). Importantly, this fatality rate remains an estimate. The percentage of asymptomatic and extremely mild cases is still being researched, as such patients tend not to seek a diagnosis. As such, the actual fatality rate may be much lower.

Table 1.

Fatality Rates and Infection Rates of COVID-19 and Other Epidemics

\begin{tabular}{l|c|c}
\multicolumn{2}{|c|}{ Fatality rate (deaths/cases) } & Infection rate (per infected person) \\
\hline Ebola & $50 \%$ & $1.5-2.5$ \\
\hline MERS & $34.30 \%$ & $0.42-0.92$ \\
\hline SARS & $10 \%$ & 3 \\
\hline COVID-19 & $1 \%-3.4 \%$ & $1.5-3.5$ \\
\hline Seasonal flu & $0.05 \%$ & 1.3 \\
\hline
\end{tabular}

Source: Asian Development Bank Report No. 128

(https://www.adb.org/publications/economic-impact-covid19developing-asia)

By the end of March 2020, more than 100 countries had implemented full or partial lockdown measures for the first time in over a century. Publics were put under surveillance, and government policies allowed surveillance technologies to be used to monitor citizens' every activity and change. Social distancing policies were implemented, and people were urged to stay at home whenever possible. Intimate socialisation, such as talking, hugging, kissing, and even hand-shaking, became seen as morbid. As lockdowns were implemented, air traffic rates dropped; many countries even stopped all flights (Dunford et al., 2020). According to David 
Spiegel, a professor of psychiatry and behavioural sciences at Stanford University, we are training people to see the world as a dangerous place (Cummins, 2020). This has resulted in new behaviours and created a new culture, and consequently the world will never be as it was. Still, we are facing an emergency when decisions must be made quickly and decisively, and new approaches must be accepted and practised (Harari, 2020).

COVID-19 posits insurmountable obstacles for international actors-state actors, non-state actors, intergovernmental organisations, and even supranational bodies-in achieving their short and longterm objectives. As the virus does not 'pick and choose' its victims, it may not even be far-fetched to deem it a global crisis. International cooperation is the only potential catalyst for fighting the virus. Considering international actors' different anatomies of power, authority, and manoeuvrability, they offer distinctive mosaics of responses when working individually. This reflects on the diverse modus operandi used by actors to achieve their objectives, which may share commonalities but nonetheless serve as distinguishing factors.

Let us take, for example, the state. With the strength of 'infinite' sovereignty, the state can boost its authority and reduce stonewalling in managing its COVID-19 countermeasures. Sovereignty enables states to choose whether or not they will work with other actors (states, international organisations, and private actors) to deal with COVID-19. Some have chosen to reject outside assistance, as seen in Iran's rejection of aid from the United States (United States Institute of Peace, 2020), and the WHO's difficulty making states follow its guidance (Buranyi, 2020). Arguably, international organisations and institutions, particularly ones that are 'intergovernmental' in nature, are inconsequential to states, whose persistent utilisation of sovereignty in dealing with COVID-19 is unanimously accepted by realism, a school of thought that deifies states' sovereignty.

International society has boldly embraced nationalism and xenophobia. As such, the pendulum has swung in favour of realism, painting a gloomy picture of international organisations and institutions' role and authority in responding to COVID19. It is therefore interesting to consider and explain the reality of global COVID-19 countermeasures through the lens of cosmopolitanism. The goals of this study are two-fold. First, this article intends to use the concepts of cosmopolitanism to provide theoretical criticism of the world's COVID-19 countermeasures. Second, it aims to offer modest suggestions, again taking a cosmopolitan view, of what international society should do in the future to deal with the virus.

\section{Research Methods}

This study is conducted using the qualitative research method, with a case study approach. This methodology enables us to obtain an in-depth analysis of attitudes, events, and social phenomenon (McCusker, 2015). Qualitative research allows researchers to obtain knowledge through understandings and findings (Iskandar, 2009). This study, thus, tries to comprehend COVID-19-related social dynamics and issues to obtain knowledge relevant to the authors' analysis. The researchers also used library research to 
collect valid data related to COVID-19 and cosmopolitanism from secondary resources, such as books, journals, websites, government reports, and newspapers (Raco, 2018).

\section{Theoretical Framework: Cosmopolitanism}

Cosmopolitanism traces its roots to three events. The fall of the Soviet Union has been seen as the first milestone in the history of cosmopolitanism, and indeed the theory has been seen as the key to realising human rights, upholding democracy, and even strengthening the United Nations. Second, cosmopolitanism has also been driven by the need to encourage international collaboration for addressing environmental issues. Third is globalisation, a significant milestone that always emphasises cosmopolitanism values (Calhoun, 2017). As the world has become intentionally integrated, new challenges have emerged for everyone. These challenges must be accounted for in the cosmopolitan agenda.

Also contributing to the increased attention received by cosmopolitanism is an ongoing concern regarding ethnic warfare (Canovan, 2000). Universalising values, as emphasised by cosmopolitanism, was seen as the best way to deal with these demonised and pardonless conflicts (Catterall, 2011). As the reputation of cosmopolitanism increased, scholarly debate on cosmopolitan issues mushroomed. A surge of writings appeared, and cosmopolitanism has become a subject of much research, debate, and controversy in the social sciences (Inglis, 2012).

Immanuel Kant proposes 'Three Definitive Articles' (Scheid, 2011) that, in short, explain the ideal form of state, the need to form a federation, and cosmopolitan rights. He argues that the republic is the ideal form of state, and that world peace can be realised by developing a worldwide federation wherein people are granted legal protections under international law. As he believes that states are naturally anarchic, he holds that the creation of an international federation is necessary to maintain mutual security (Rauscher, 2017)

Supporting the concepts of cosmopolitanism, in his third definitive article "Perpetual Peace" Kant offers the idea of cosmopolitan rights He proposes a 'universal civic society', in which individuals are treated as subjects and enjoy fundamental human rights. He believes that cosmopolitan rights can ensure that people communicate with each other and work toward realising a world federation. Kant holds that all foreigners have the right to hospitality, and that all individuals may travel freely around the world without facing hostility (Alvian, 2015). He justifies this with the 'right of surface', which holds that humanity enjoyed common ownership long before the land was bound by nationstates. Hence, according to Kant's view of cosmopolitan rights, foreigners who travel through other countries must not be subjected to arbitrary treatment, so long as they come peacefully; in other words, foreigners are strictly forbidden from exploiting native inhabitants. Kant's right to hospitality highlights his view that individuals enjoy political emancipation and equal freedom in the communication process.

In a political context, the concept of cosmopolitanism was recently explored by the scholar Nigel Dower (2007), who argues 
that we can see human beings as members of a global legal community. Core to this is the belief that human beings exist in a single 'moral community', seen as having (interpreted) interdependence, shared traditions and norms, and some sort of commitment to the whole. Dower's idea of political cosmopolitanism is oriented towards the thought of what makes someone a global citizen afterwards. It firmly asserts that, in principle, we all have a responsibility towards human beings around the world. Likewise, everyone can commit in various ways to make a difference by becoming involved in acts of global responsibility. Such acts are clearly needed to deal with global issues such as world poverty, environmental damage, war, disease, etc.

The transformation of institutions and practices from state-oriented to globaloriented is necessary for cosmopolitanism to materialise its 'imagined' community. Cosmopolitanism is not merely a freefloating cultural taste, a personal attitude, or a political choice; it is a matter of institutions (Saito, 2011). In this regard, cosmopolitanism favours the institutionalisation of world society through the establishment of inter-governmental and/or international non-governmental organisations. Such organisations would act as bridges for the diffusion of ideas, values, and norms that define people as global citizens. Moreover, such international bodies should later be modified to become more democratic, thereby enabling them to fully support world citizens becoming engaged in foreign policy decisions without including nation-states. Such institutions must advance the realisation of global goals, rather than serve as arenas for accommodating states' interests. Regarding the issue of intervention, institutions should not be rooted in nationstates, but rather premised on the world citizen. This will not only promote global citizenship, but also underpin the idea that the world is a community of humans rather than an aggregation of nation-states.

In a nutshell, cosmopolitanism is rooted in several ways of thinking. First, it argues that too much respect for ethnic and cultural differences undermines attempts to enforce global citizenship and realise universal human rights. Therefore, it tries to abolish such emphasis on nationstates and their differences, both discreet and blatant. Second, cosmopolitanism is often oriented towards establishing transnational work relations; national boundaries, thus, only pose barriers to their success. Third, as implied by its very name-'cosmos' meaning 'whole'cosmopolitanism stresses true 'universality', and as such cosmopolites are understood as 'citizens of the world'. Fourth, cosmopolitanism no longer adheres to the concept of 'nation'. For explanation, we may turn to a parable offered by Stefano Recchia and Nadia Urbinati. Once upon a time, a cosmopolite said, "We are more advanced than you." They continued, "We no longer believe in the nation, we believe in humanity, we are Cosmopolitans" (Recchia \& Urbinati, 2009). Fifth, cosmopolites aspire for the subordination of self-regard and selfinterest, when required for the betterment of the broader global community (Moore, 2013). Though cosmopolitanism is often perceived by states more as a threat than a boon, since it opposes national identity (Bowden, 2003), its way of thinking must be 
given careful consideration by the international society.

Nevertheless, the return of infectious disease has proven a tragedy for the international community. Obstacles to mitigation efforts lie not only in the limited resources of human, state, and international actors, but also in reduced cooperation between them. In this situation, excessive reverence for sovereignty and nationalism, as well as the emergence of xenophobia, have further impaired such cooperation. Having plunged into the depths of cosmopolitanism's ocean of thought, this paper will now identify how cosmopolitanism excoriates countermeasures to COVID-19, as well as the action plans that it advocates for better dealing with the pandemic.

\section{Literature Review}

COVID-19 led to cosmopolitanism becoming increasingly notorious within the discourses of international relations. Even before this study's publication, numerous works related to COVID-19 and cosmopolitanism have been published and offered diverse ideas. Igor Calzada believes that the pandemic has brought cosmopolitan globalisation, wherein people have the freedom to move, work, and travel without limits, to the verge of collapse. People now are 'pandemic citizens', an eye-catching term Calzada coins to refer to those who are "increasingly stuck inside closed nation-states surrounded by contradictory new walls and old borders". Realising that governments and other organisations could easily abuse citizens' data for unfair or unethical purposes, Calzada's proposes that states and other organisations should be committed to using existing data in a good manner. They must not use the pandemic to justify the weakening of the values of democracy and the abrogation of citizens' rights, regardless of where they are located on the planet (Calzada, 2020).

COVID-19's harmful effect on humanity cannot be separated from globalisation, one of cosmopolitanism's core elements. Tabak (2020) mentions that globalisation is strongly correlated with COVID-19, and underscores that COVID-19 has proven a common threat to allrecognizing neither nationality nor race. Therefore, the validity of national solutions as COVID-19 countermeasures is questionable. Tabak proposes two crucial points that support globalisation as a political discourse in the post-pandemic era: first, states' consciousness of the importance of embracing cooperation to deal with a crisis, and second, the enhanced interconnectedness of humanity.

Hwang Jin-tae (2020) analyses the atmospheres of social stigma in three different Korean cities (Seoul, Daegu, and Gwangju). He concludes that global society must welcome the experiment of cosmopolitanism, which can challenge stigma and providing an essential catalyst for socialising unsocial sociability to fight the virus. Terri-Anne Teo (2020) discusses how economic nationalism gave birth to protectionist government policies, as well as xenophobia and racism. She posits that the ethos of moral cosmopolitanism can have a positive impact on the community. Nevertheless, she emphasises that cosmopolitanism should not be considered a substitute for nationalism, as nationalism has exclusionary properties that are essentially detrimental to social cohesion. 
Teo believes that "moral cosmopolitanism and nationalism are not fundamentally opposed, but are effectively two sides of a coin" (Teo, 2020).

Compared to this criticism, cosmopolitan proposals have been downplayed. In this light, this paper intends to provide a slightly different approach. Unlike Teo and most other scholars' criticism of 'economic nationalism', this study focuses on the rapid growth of 'health nationalism' and tracks the presence of xenophobia in the everyday life of international society. This study also employs a cosmopolitan perspective to make two major proposals. First, this study holds that cosmopolitanism recommends that international actors endorse multilateralism and emphasise its effectiveness. Second, cosmopolitanism suggests that the international community favour solidarity-based countermeasures over exclusionary health aid.

\section{Discussion}

Health Nationalism; How It Makes World's COVID-19 Countermeasures 'Go Down in Flames' in the Lens of Cosmopolitanism

Florian Bieber (2018) has a metaphor "Like air, nationalism is both ubiquitous and elusive". Nationalism permeates the global system, as well as the behaviour of states and international society. Over the past few years, a rising tide of nationalism has been seen in every corner of the world. It has deepened and broadened, from the election of Donald Trump (who adhered to the principle of nationalism on a daily basis) in the United States (Rachman, 2018; Crowley \& Sanger, 2019; Schertzer \& Woods, 2020), the United Kingdom's decision to bring down its flag in European Union's headquarters in Brussels (Serhan, 2019), the nationalist policies of the Japanese Prime Minister Shinzō Abe (Surak, 2019, Leheny, 2019), the bold sense of ethnocentrism of India's Narendra Modi (Naqvi, 2020), the rise of Turkish president Recep Tayyip Erdoğan's nationalism (Kasaba, 2018), the success of far-right parties in the Italian, German and Austrian elections in 2017 and 2018 (Bieber, 2018), the escalation of disputes between the claimants of the South China Sea (China, the Philippines, Vietnam, etc.) (Alfieri \& Vukovic, 2018), as well as in South Africa's efforts to impede multilateral bodies such as the International Court of Justice (BBC News, 2017).

"The pandemic will strengthen the state and reinforce nationalism. Governments of all types will adopt emergency measures to manage the crisis, and many will be loath to relinquish these new powers when the crisis is over". - Stephen M. Walt (2020)

Walt's argument is probably justifiable. Despite sharing the common problem of COVID-19, states still show no sign of reducing their nationalism, and its spectre continues to underpin their interaction. Other facts further bolster this argument. Take, for example, the 'economic nationalism' that has been broadly discussed in international relations as trade wars have become more common. In the context of the COVID-19 pandemic, the debate now focuses on 'health nationalism'. Governments around the world have struggled to protect their own 
health supplies as the novel coronavirus has driven panic buying, hoarding, and even theft (The Local, 2020). As the consequence, to ensure that their health workers and populaces have sufficient supplies to deal with the coronavirus outbreak, several countries have reduced or even stopped the export of medical supplies that are essential for their neighbours' frontline actions and preventive efforts.

Let us consider how such 'health nationalism' has manifested in reality. In early March 2020, a truck full of medical supplies was stopped at the GermanSwiss border, after German chancellor Angela Merkel banned the export of protective medical equipment. This truck, carrying 240,000 face masks, was planned to help replenish Switzerland's rapidly diminishing stock (Dahinten \& Wabl, 2020). Similar export bans were also issued by the Czech Republic, France, and other European countries (Wynne, 2020) When Italy, the European epicentre of the COVID19 pandemic, requested urgent medical supplies under a special European crisis mechanism, not a single EU member state responded; indeed, they became even more eager to ban the export of medical equipment, as they feared having the same shortage. This implied that Italy had been abandoned by its European friends (Hall, Johnson, \& Arnold, 2020). Over time, however, the European Union tried to encourage its member states to be more receptive to medical tools exports (Guarascio \& Blenkinsop, 2020). Ultimately, both France and Germany lifted their export bans (Web24 News, 2020)

Such a gloomy situation also occurred in North America, when the United States refused to send medical equipment to Canada and Latin America. 3M, a multinational conglomerate headquartered in the United States, was instructed by the Trump administration to stop exporting N95 face masks to the Canadian and Latin American markets. This move, critics argued, would result in a crisis of respiratory supplies in Canada and Latin America, where $3 \mathrm{M}$ is the paramount supplier of respirators for healthcare workers (Turnbull, 2020). As in Germany and France, the United States justified its decision by citing its desire to secure domestic demands (Forrest, 2020).

It is common for countries to prioritise themselves in world politics. However, when crises affect all, such political intentions have wrought nothing but darkness. Countries' decision to prioritise themselves is misplaced. As argued by cosmopolitanism, human beings are all subjects who possess equal human rights and equal standing as members of the global legal community. Therefore, nation-states must respect human rights (in this case, health rights), and the COVID19 pandemic must be understood as a global responsibility. In this regard, countries' reluctance to help their neighbours is not only problematic for cosmopolitanism; it is a stumbling block for global society's collective efforts to counter the spread of COVID-19. If the ideals of cosmopolitism are upheld, countries will not need to fear losing their health supplies, as all countries can protect and assist each other. For example, if Country $A$ is having a crisis of health supplies, Country B can send aid. So long as Country $B$ is not in the same situation as Country $A$, there is nothing wrong with providing assistance. Likewise, when Country B is experiencing distress, Country 
A can provide support and pay a debt of gratitude.

During pandemics, refugees and migrants are the most vulnerable elements of society. Nationalism gives them little room to receive proper treatment or be involved in COVID-19 countermeasures. In most countries, they are over-categorised as homeless populations and face uncertainty in their legal status. In this vein, refugees and migrants often face obstacles when accessing sanitation facilities, healthcare services, and medicines (World Health Organisation, 2020). To alleviate this situation, host countries should include refugees in their national COVID-19 countermeasure frameworks (Husein \& Maulana, 2020). In the eyes of cosmopolitanism, ignoring refugees would be a major mistake, as they too have human rights that must be advocated without discrimination. The words of Jacquelyn Corley (2020) deserve to be mentioned in this regard,

"The coronavirus respects no national borders, nor does it honor some ethnic heritages over others. Thus, segregation and nationalism will only weaken countries who have received refugees". - Jacquelyn Corley

\section{Xenophobia: Another Stonewall Against Cosmopolitanism}

Xenophobia has become an ugly child of COVID-19, even in China, where the first case was reported. As China says that most of its current cases are imported, antiforeigner stances have become commonplace. In Shanghai and Beijing, foreigners have been prohibited from entering some shops, gyms, and offices. When foreigners stroll outside, locals cover their noses or move away (Qin \& Wang, 2020). In the United States and Europe, meanwhile, 'anti-Asian' sentiments have flourished-ironically, at times within the government. For instance, President Donald J. Trump's decision to identify COVID-19 as the 'Chinese virus' (Vang, 2020) provoked anti-Asian sentiments throughout the United States. As a result, numerous cases of physical and verbal violence against people of Chinese heritage have been commonplace. Hate speech has often targeted Asian-Americans as well as Asian-looking foreigners in the United States, reflecting broader stigmas and a belief that a specific country or ethnicity can be blamed for the pandemic. According to L1ght, a company focused on detecting and filtering toxic online content, Twitter has seen a $900 \%$ increase in hate speech regarding China and Chinese people (L1GHT, 2020).

In Europe, too, xenophobia has found fertile ground during the pandemic. Matteo Salvini, the League Party Leader of Italy, erroneously connected the COVID-19 to African asylum seekers (Tondo, 2020). In London and the Netherlands, many Asian students have been attacked by locals. This has occurred not only in the streets, where locals have been seen to yell at random Asians, but also in schools (Lau, 2020).

Anti-immigration policies were also evident in Hungary (Mutsvara, 2020). One government official, György Bakondi, linked the pandemic with illegal migration, and thus officially and indefinitely suspended the admission of illegal migrants into the transit zone. The government even prepared to strengthen its borders, not allowing any illegal migrants to enter (Gall, 
2020), and this showed us how countries have weaponised COVID-19 to spark the flame of xenophobia and to create fear of foreigners. The coronavirus has exacerbated tensions between locals and immigrants, who have been perceived as carriers of the virus.

Cosmopolitanism promotes an idea of 'global identity', wherein ethnic and cultural diversity are greatly respected, global citizenship is acknowledged, and human rights are protected. This calls for an ideal of unity and equality afterwards. We have seen that COVID-19 is not only a health issue, but also a social one, having been used to justify xenophobia. The world seems to have preferred exploiting fear rather than embracing a global identity. In the short term, xenophobia does not only cause mental and physical harm to certain groups, but also makes them fear seeking help (Ramirez, 2020). In the United States, for instance, enforcement actions-i.e., detention and raids by Immigration and Customs Enforcement (ICE)-have resulted in immigrants being unwilling to seek help if they are showing symptoms (Ramirez, 2020). This leaves them vulnerable, as they choose to conceal their symptoms instead of seeking medical care, for fear that it will result in their deportation or prevent them from obtaining permanent residency in the future (McFarling, 2020).

Countering the pandemic requires global action, but if xenophobia still permeates international relations, such action cannot be effectively realised. Global action requires the solidarity of peoples around the world, without any ethnic or national barriers. States must commit themselves not to harming others, but rather helping them respect the essentials of human well-being.
Governments should work to provide proper health facilities to everyone, including foreigners, rather than encourage xenophobic rhetoric.

The transmission of the novel coronavirus will not easily stop if people are treated differently. We are witnessing how immigrants, foreigners, refugees, and certain ethnic groups are at higher risk for not receiving medical care due to xenophobic hysteria. In responding to COVID-19, governments should not use xenophobic policies, but rather guarantee equal and non-discriminatory treatment for all human beings, irrespective of their nationality, citizenship status, or displacement (Zolberg Institute on Migration and Mobility, 2020). Medical aid is essential for everyone, and governments should ensure that they can provide prevention and treatment without discrimination. In the ongoing war with the pandemic, ignoring one aspect of human well-being will effectively block all efforts to stop the transmission.

As mentioned by Tendayi Achiume (2020), the UN Special Rapporteur on racism, on the International Day for the Elimination of Racial Discrimination: "Crises like the coronavirus pandemic remind us that we are all connected and that our well-being is interdependent". This statement reminds us that, as human beings, we have the responsibility to be involved in any disaster mitigation effort, as it has been shown that our essential value as human beings can be best realised through interdependence and shared norms, values, and commitment (Dower, 2007). If states continue to blame particular communities for the virus, any actions to combat this issue will be useless afterwards. Ethnicity and nationality must 
not be excuses for not dealing with COVID19. Social inclusion, justice, and solidarity are needed to establish health protection, and thus focus on any of humans' multifaceted identities will pose barriers for the creation of a shared commitment to realising global aims.

\section{First Proposal: Global Integration through Multilateralism}

COVID-19 is a global calamity, and as such global integration would be the best possible means of addressing it. Global integration will broaden and deepen international society's awareness that humans possess global citizenship, therefore producing a shared identity, commitment, and interest that would improve adherence to human rights. The disease is borderless, spreading widely without concern for national borders. No state can escape the novel coronavirus, and it may even return to countries that considered themselves free of it. States, be they large or small, developed or underdeveloped, rich or poor, share a common interest; to counter this pandemic as soon as possible. To effectively realise such integration, states require multilateralbased cooperation $(\mathrm{Ng}, 2020)$.

Multilateralism can be understood as occurring when three or more states that share similar concerns decide to coordinate, standardise, and formalise their actions (Keohane, 1990; Ruggie, 1992). It may be embodied in international treaties or agreements, realised through international organisations and institutions, and be achieved through international conferences and summit meetings. Considering that cosmopolitanism requires the institutionalisation of ideas, such multilateralism may be understood as the means through which global integration, global citizenship, single identity, and parallel commitment can be materialised. By bringing several states to the table, multilateralism would enable them to establish, implement, and administer sets of rules that utilise cosmopolitan ideas to increase synergy in COVID-19 countermeasures. Even before the COVID19 pandemic, multilateralism was facing a crisis as a result of rising cynicism, distrust, nationalism, populism, and authoritarianism (Ng, 2020; Linn, 2018). It has thus become a rare commodity in this day and age. Since multilateralism is paramount for generating global integration, and thus for improving global countermeasures to COVID-19, states must stop impeding its implementation and welcome its cultivation.

Supporting global integration through multilateral means is important. As already stated, COVID-19 calls for a global solution. When states prefer to work alone, their efforts to counter the pandemic can only produce a stalemate. Buckminster Fuller's analogy supports this notion,

"We have today, in fact, 150 supreme admirals and only one ship Spaceship Earth. We have the 150 admirals in their 150 staterooms, each trying to run their respective stateroom as if it were a separate ship. We have the starboard-side admirals' league trying to sink the port side admirals' league. If either is successful in careening the ship to drown the 'enemy' side, the whole ship will be lost". - Buckminster Fuller (1990, in Pegram, 2020) 
Rather than work alone or, worse, compete with each other in the name of national interests, we should bear in mind that we are global agents who are working in the name of all inhabitants on Spaceship Earth (Pegram, 2020). In dealing with COVID-19, global society faces two cumbersome issues: food shortages and vaccine distribution. Even before the pandemic, economic recession, extreme weather, and conflict led to 135 million people in 55 countries experiencing acute hunger (World Food Programme, 2020); figures were expected to potentially double by the end of 2020 (Anthem, 2020). Health, needless to say, is a priority. Nevertheless, we cannot ignore that the availability of sufficient healthy food must be a cornerstone of any pandemic response. As such, it is necessary to not only ensure the sustainability of the global food supply chain, but also to ensure that food remains accessible to all (Cantillo, 2020). To accomplish this goal, incisive and inclusive coordination-realized through multilateralism-must permeate international relations. States, being essential in ensuring food availability, should abolish the principal barriers (lack of trust, nationalism, populism, protectionism, isolationism, and authoritarianism) that limit their ability to join or create multilateral responses to COVID-19.

The world now depends on vaccines designed to treat the novel coronavirus. A high quantity of dosages will need to be mass-produced, and therefore collaboration between regulators, industry, and the scientific community will be of utmost importance (Edmond, 2020). Efforts must be made to avert contamination, scale down transmission, and build herd immunity, as even an effective vaccine is useless if distributed ineffectively. Historically, some states have prioritised their citizens, creating a discrepancy in vaccine distribution both within and among countries (Bollyky, Gostin, Hamburg, 2020). Take, for example, how wealthy nations bought out entire vaccine supplies during the Influenza $A$ (H1N1) pandemic of 2009 (Whalen, 2020, in Bollyky, Gostin, Hamburg, 2020). To prevent a recurrence, states should commit themselves to the equal distribution of vaccines through multilateral means; this could be by giving birth to new international norms, by conducting special multilateral meetings as a coordination step, or at least by obeying the instructions of existing multilateral organisations.

\section{Second Proposal: Prevent Exclusionary Health Aid through Solidarity-based Countermeasures}

We are seeing that governments and stakeholders have only been able to consider COVID-19 narrowly, without considering vulnerable members of society such as migrants and refugees. Amidst rampant nationalism and the rise of xenophobic rhetoric, states cannot identify measures for countering COVID-19 without prejudice, and such nationalist approaches to health will be detrimental to certain communities. Furthermore, the idea of prioritising certain individuals runs contrary to the global responsibility to counter COVID-19, as it hinders the implementation of global unity. As they are not considered priorities, certain groups will be absent from health assistance projects. It is these groups-refugees and migrants, in many 
cases-who are at the highest risk during the ongoing pandemic.

"If the current pandemic leads to a two or even three-tier mobility system, then we will have to try to solve the problem - the problem of the pandemic - but at the same time, we have created a new problem of deepening the inequalities.". - António Vitorino

This statement (UN News, 2020) clearly denotes the current situation that we are facing today. Several stateimplemented policies have given rise to new problems that have yet to be considered. Mobility restrictions, including lockdown policies, may have never been effective countermeasures, and instead may have only harmed migrants. As seen in several states, lockdowns have affected migration processing and the provision of assistance to asylum seekers. On 17 March 2020, the United Nations High Commissioner for Refugees (UNHCR) and International Organisation for Migration (IOM) announced the suspension of resettlement departures for refugees due to mobility restrictions in over 180 countries. As a result, refugees were forced to live in extreme conditions in border camps, where a lack of medical care has left them vulnerable to being exposed to the virus. States, therefore, must ensure that aid reaches migrants and refugees by asserting a solidarity-based solution.

Solidarity is linked to 'universal, moral standards', which allow for the prioritisation of solidaristic action without excluding people based on ethnic and religious considerations (Kapeller \&
Wolkenstein, 2013). Such a solution also supports the realisation of interconnection and interdependence, providing a common interest and aim that further buttressed unity (Parsanoglou, 2020). As noted by Kant, the concept of solidarity also encompasses a duty to stand in solidarity to prevent others from coming to harm (Straehle, 2020). Barriers impeding migrants and refugees will only exacerbate the impact of COVID-19, and thus states' responses to the pandemic must include national plans to address the problems. Measures should reach all migrants and refugees, regardless of their legal status, ethnic background, or nationality. All human beings merit equal access to information, health care services, and Personal Protection Equipment (PPE).

In implementing a solidarity-based solution, states should first abolish the policies that hamper migrants and refugees, including travel restrictions and related enforcement actions. Social distancing and self-isolation, for instance, cannot be readily realised amongst migrants due to their lack of access to housing, as well as their continued suspicion of authorities so long as the threat of enforcement actions remains (World Economic Forum, 2020). It is necessary to process migrants and refugees promptly, thereby ensuring certainty for all. States should guarantee that everyone, citizen, migrant, and refugee alike, receives non-discriminatory service. Movement restrictions and border closure measures must comply with international law and be proportionate and reasonable to the aim of protecting public health. At the same time, a solidarity-based countermeasure must ensure that migrants and refugees are treated 
humanely and that their rights under international law are respected. Only then can it be ensured that no migrants are left behind.

We should unite to establish equal services that protect human lives. Nationality or citizenship should not determine who receives protection and who does not (Triandafyllidou, 2020). States should not prioritise 'insiders' while discarding 'outsiders', but instead promote solidarity and defend the most vulnerable. This crisis provides a potent reminder that we have a duty not only to local citizens, but to all of humanity.

\section{Conclusion}

International society should have faith in cosmopolitanism and its offerings, as its criticisms and proposals offer the most relevant weapons for mitigating the erroneous global actions that have been implemented to tackle the virus almost overnight. States' actions, often reflecting health nationalism and xenophobia, have posed significant-and perhaps insurmountable-obstacles to proper countermeasures. Nationalism and xenophobia are 'powder kegs' that threaten the world's efforts to realise global integration and integrative solutions. Cosmopolitanism would instead, as this paper shows, suggest that international society employ a multilateral approach as the most suitable means of harvesting the fruits of global integration. Moreover, cosmopolitanism emphasises that society's most vulnerable members, such as migrants and refugees, should receive careful attention. Exclusionary health aid must give way to solidarity-based countermeasures.

Kant offers the idea of cosmopolitan rights in his third definitive article, holding that they "should be limited to conditions of universal hospitality". We admit that the current world order is lacking, or even bereft of, such universal hospitality, being instead of an unsupportive environment replete with bold nationalism and other concepts that divide humans into various factions. This does not mean that cosmopolitanism cannot fit into this era of anarchic world order. Indeed, our proposals to enhance global integration by using multilateral means and avoiding exclusionary health assistance. Solidaritybased countermeasures could create conditions of universal hospitality, and as such these two efforts may help realize cosmopolitan rights.

It is true and inevitable that cosmopolitanism is the reason for the COVID-19 pandemic's explosive growth. The idea of free international travel, as proposed by cosmopolitanism, has contributed significantly to the current crisis. However, cosmopolitanism also proposes a solution, a series of countermeasures that may contribute to disaster mitigation efforts. Cosmopolitanism, it can be seen, can be crucially involved in pandemic countermeasures. 


\section{References}

Achiume, T. (2020, March 21). States should take action against COVID-19-related expressions of xenophobia, says UN expert. United Nations Human Rights Office of the High $\begin{array}{lllll}\text { Commissioner. } & \text { Retrieved } 20 & \text { May } & 2020 \text { from }\end{array}$ https://www.ohchr.org/EN/NewsEvents/Pages/DisplayNews.aspx?NewsID=25739\&La $\mathrm{ngID}=\mathrm{E}$.

Alfieri, R., \& Vukovic, S. (2018). Bumping, precedents, and de-escalation in South China Sea: options for the United States and China. Asia \& the Pacific Policy Studies, 5(3): 665-671. https://sci-hub.tw/10.1002/app5.248

Alvian, A. R. (2015). Perbandingan gagasan Immanuel Kant dan Jacques Derrida atas konsep hak kosmopolitan atas keramahan (cosmopolitan right of hospitality). Cogito, 2(1). https://www.academia.edu/32431122/Perbandingan_Gagasan_Immanuel_Kant_dan_J acques_Derrida_atas_Konsep_Hak_Kosmopolitan_atas_Keramahan_Cosmopolitan_Rig ht_of_Hospitality.

Anthem, P. (2020, 16 April). Risk of hunger pandemic as COVID-19 sets to almost double acute hunger by end of 2020. World Food Programme. Retrieved 25 May 2020 from https://insight.wfp.org/covid-19-will-almost-double-people-in-acute-hunger-by-end-of2020-59df0c4a8072.

Asian Development Bank. (2020). The economic impact of the COVID-19 outbreak on developing Asia. Department of Communications. Manila: Asian Development Bank. https://www.adb.org/sites/default/files/publication/571536/adb-brief-128-economicimpact-covid19-developing-asia.pdf.

BBC News. (2017, 1 February). African Union backs mass withdrawal from ICC. Retrieved 16 May 2020 from https://www.bbc.com/news/world-africa-38826073.

Bieber, F. (2018). Is nationalism on the rise? Assessing Global Trends. Ethnopolitics, 17(5): 519-540. https://www.tandfonline.com/doi/pdf/10.1080/17449057.2018.1532633.

Bollyky, J. T., Gostin, O. L., \& Hamburg, A. M. (2020). The equitable distribution of COVID-19 therapeutics and vaccines. JAMA. Retrieved 25 May 2020 from https://jamanetwork.com/journals/jama/fullarticle/2765944.

Bowden, B. (2003). Nationalism and cosmopolitanism: irreconcilable differences or possible bedfellows?. National Identities, 5(3): 235-249. https://booksc.xyz/dl/31583045/2358fc.

Buranyi, S. (2020, 10 April). The WHO v coronavirus: why it can't handle the pandemic. The $\begin{array}{lllll}\text { Guardian. } & \text { Retrieved } & 3 & \text { May } & 2020\end{array}$ https://www.theguardian.com/news/2020/apr/10/world-health-organization-who-vcoronavirus-why-it-cant-handle-pandemic.

Calhoun, C. (2017). A cosmopolitanism of connections. In K. Appiah (author), B. Robbins, \& P. Horta (eds.), Cosmopolitanisms (pp. 189-200). New York: NYU Press. DOI: $10.2307 /$ j.ctt1gk09g6.18. 
Calzada, I. (2020, 19 March). Will Covid-19 be the end of the global citizen?. Apolitical. Retrieved 28 May 2020 from https://apolitical.co/en/solution_article/will-covid-19-bethe-end-of-the-global-citizen.

Canovan, M. (2000). Patriotism is not enough. British Journal of Political Science, 30(3): 413432. https://booksc.xyz/dl/53564026/c21350

Cantillo, S. V. M. (2020, 7 May). Asia-Pacific must take urgent action to tackle COVID-19's recession-induced hunger. The Jakarta Post. Retrieved 25 May 2020 from https://www.thejakartapost.com/academia/2020/05/07/asia-pacific-must-take-urgentaction-to-tackle-covid-19s-recession-induced-hunger.html.

Catterall, P. (2011). Democracy, cosmopolitanism and national identity in a 'globalising' world. National Identities, 13(4): 329-347. https://booksc.xyz/dl/20941278/115d50.

Crowley, M., \& Sanger, E. D. (2019, 24 September). Trump celebrates nationalism in U.N. speech and plays down Iran crisis. The New York Times. Retrieved 16 May 2020 from https://www.nytimes.com/2019/09/24/us/politics/trump-nationalism-unitednations.html.

Corley, J. (2020, 21 April). Why refugees are the world's most vulnerable people during the COVID-19 pandemic. Forbes. Retrieved 19 May 2020 from https://www.forbes.com/sites/jacquelyncorley/2020/04/21/why-refugees-are-theworlds-most-vulnerable-people-during-the-covid-19-pandemic/\#2e1c94041128.

Cummins, E. (2020, 22 April). The legacy of the pandemic: 11 ways it will change the way we live. Vox. Retrieved 30 April 2020 from https://www.vox.com/thehighlight/2020/4/16/21213635/coronavirus-covid-19-pandemic-legacy-quarantinestate-of-mind-frugality.

Dahinten, J., \& Wabl, M. (2020, 9 March). Germany faces backlash from neighbors over mask export tires. Bloomberg. Retrieved 17 May 2020 from https://www.bloomberg.com/news/articles/2020-03-09/germany-faces-backlash-fromneighbors-over-mask-export-ban.

Dower, N. (2007). Cosmopolitanism theories. Edinburgh: Edinburgh University Press.

Dunford, D., Dale, B., Stylianou, N., Lowther, E., Ahmed, M., \& Arenas, I. d. (2020, 7 April). Coronavirus: the world in lockdown in maps and charts. BBC News. Retrieved 29 April 2020 from https://www.bbc.com/news/world-52103747.

Edmond, C. (2020). 3 challenges in creating a coronavirus vaccine - and how they are being overcome. World Economic Forum. Retrieved 25 May 2020 from https://www.weforum.org/agenda/2020/05/coronavirus-covid-19-vaccine-industry/.

Forrest, M. (2020, 4 March). Trudeau warns U.S. against denying exports of medical supplies to Canada. Politico. Retrieved 19 May 2020 from https://www.politico.com/news/2020/04/03/3m-warns-of-white-house-order-to-stopexporting-masks-to-canada- 163060. 
Gall, L. (2020, 19 March). Hungary weaponizes coronavirus to stoke xenophobia. Human Rights Watch. Retrieved 20 May 2020 from https://www.hrw.org/news/2020/03/20/hungaryweaponizes-coronavirus-stoke-xenophobia.

Guarascio, F. \& Blenkinsop, P. (2020, 6 March). EU fails to persuade France, Germany to lift coronavirus health gear controls. Reuters. Retrieved 19 May 2020 from https://www.reuters.com/article/us-health-coronavirus-eu/eu-fails-to-persuade-francegermany-to-lift-coronavirus-health-gear-controls-idUSKBN20T166.

Hall, B., Johnson, M., \& Arnold, M. (2020, 14 March). Italy wonders where Europe's solidarity is as coronavirus strains show. Financial Times. Retrieved 19 May 2020 from https://www.ft.com/content/d3bc25ea-652c-11ea-b3f3-fe4680ea68b5.

Harari, Y. N. (2020, 20 March). Yuval Noah Harari: the world after coronavirus. Financial Times. Retrieved 30 April 2020 from https://www.ft.com/content/19d90308-6858-11ea-a3c91 fe6fedcca75.

Husein, R., \& Maulana, Z. (2020, May). Pandemi global dan upaya perlindungan pengungsi. Centre for Development and International Studies (Issue Brief No. 1). https://hi.umy.ac.id/umy-terbitkan-policy-brief-1-global-pandemic-and-the-protection-ofrefugees/

Iskandar. (2009). Metodologi penelitian kualitatif. Jakarta: Gaung Persada.

Inglis, D. (2012). Alternative histories of cosmopolitanism. In G. Delanty (eds.), Routledge Handbook of Cosmopolitanism Studies. London and New York: Routledge. https://bok.cc/dl/2835190/358a22.

Jin-tae, H. (2020, 16 April). COVID-19 provides cosmopolitan experiment against social stigmatization. The Korean Times. Retrieved 28 May 2020 from https://www.koreatimes.co.kr/www/opinion/2020/04/197_287724.html.

Kapeller , J., \& Wolkenstein, F. (2013). The grounds of solidarity: from liberty to loyalty. European Journal of Social Theory, 16(4): 477-491. DOI: 10.1177/1368431013479689.

Kasaba, R. (2018, 23 June). Nationalism and piety dominate Turkey's election. The Conversation. Retrieved 16 May 2020 from https://theconversation.com/nationalismand-piety-dominate-turkeys-election-98609.

Keohane, O. R. (1990). Multilateralism: an agenda for research. International Journal, (45)4: 731-764. https://booksc.xyz/dl/47933818/f3f11d.

Lau, J. (2020, 23 March). Coronavirus sparks a rising tide of xenophobia worldwide. THE World University Ranking. Retrieved 192 May 2020 from https://www.timeshighereducation.com/news/coronavirus-sparks-rising-tideofxenophobia-worldwide\#\%20.

Leheny, D. (2019, 2 August). Op-ed: Shinzo Abe's appeal to nostalgia and nationalism. Los Angeles Times. Retrieved 16 May 2020 from https://www.latimes.com/opinion/story/2019-08-01/shinzo-abe-japan-nationalismparliament-elections-postwar-history. 
L1GHT. (2020). Rising levels of hate speech \& online toxicity during this time of crisis. Tel Aviv: L1GHT.

Linn, J. (2018). Recent threats to multilateralism. Global Journal of Emerging Market Economies, 9(1-3): 86-113. DOI: 10.1177/0972063417747765.

Liu , H. Y., Manzoor , A., Wang , C. Y., Zhang , L., \& Manzoor , Z. (2020). The COVID-19 outbreak and affected countries stock markets response. International Journal of Environmental Research and Public Health, 17(8): 1-19. https://www.mdpi.com/16604601/17/8/2800/pdf.

McCusker, K. \& Gunaydin, S. (2015). Research using qualitative, quantitative or mixed methods and choice based on the research. Perfusion, 30(7): 537-542. DOI: $10.1177 / 0267659114559116$.

McFarling, U. L. (2020, 15 April). Fearing deportation, many immigrants at higher risk of Covid19 are afraid to seek testing or care. STAT News. Retrieved 20 May 2020 from https://www.statnews.com/2020/04/15/fearing-deportation-many-immigrants-athigher-risk-of-covid-19-are-afraid-to-seek-testing-or-care/.

Moore, H. (2013). The fantasies of cosmopolitanism. In R. Braidotti, P. Hanafin, \& B. Blaagaard (eds.), After Cosmopolitanism. London and New York: Routledge. https://bok.cc/dl/3487310/95f04d.

Mutsvara, S. (2020). Political rhetoric linking migration to Coronavirus stokes up xenophobia Guardian Liberty Voice. Pedagogical University of Cracow, Cracow.

Naqvi, M. (2020, 5 March). Modi's government taking Hindu nationalist agenda to 'new level'. Bloomberg. $\quad$ Retrieved $\quad 16 \quad$ May 2020 from https://www.bloomberg.com/news/articles/2020-03-05/modi-s-government-takinghindu-nationalist-agenda-to-new-level.

$\mathrm{Ng}$, Joel. (2020). Global health security - trust during the time of Covid-19. S. Rajaratnam School of International Studies. https://www.rsis.edu.sg/wpcontent/uploads/2020/03/C020041.pdf.

Parsanoglou, D. (2020). Volunteering for refugees and the repositioning of state sovereignty and civil society: the case of Greece. Citizenship Studies, 24(4): 1-18. DOI: $10.1080 / 13621025.2020 .1755158$.

Pegram, T. (2020, 5 May). Coronavirus is a failure of global governance - now the world needs a radical transformation. The Conversation. Retrieved 23 May 2020 from https://theconversation.com/coronavirus-is-a-failure-of-global-governance-now-theworld-needs-a-radical-transformation-136535.

Qin, A., \& Wang, V. (2020, 16 April). As coronavirus fades in China, nationalism and xenophobia flare. The New York Times. Retrieved 10 May 2020 from https://www.nytimes.com/2020/04/16/world/asia/coronavirus-china-nationalism.html. 
Rachman, G. (2018, 25 June). Donald Trump leads a global revival of nationalism. Financial Times. Retrieved 16 May 2020 from https://www.ft.com/content/59a37a38-7857-11e88e67-1e1a0846c475.

Raco, J. (2018). Metode penelitian kualitatif jenis, karakteristik dan keunggulannya. Jakarta: Grasindo .

Ramirez, R. (2020, 14 March). How a Chinese immigrant neighborhood is struggling amid coronavirus-related xenophobia. Vox. Retrieved 20 May 2020 from https://www.vox.com/identities/2020/3/14/21179019/xenophophia-chinesecommunity-sunset-park.

Rauscher, F. (2017). Kant's social and political philosophy. Stanford Encyclopedia of Philosophy (Spring $2017 \quad$ Edition). Retrieved 8 May 2020 from https://plato.stanford.edu/entries/kant-social-political/\#CosRig.

Recchia, S., \& Urbinati, N. (2009). Three essays on cosmopolitan ideals and national sentiment. In S. Recchia \& N. Urbinati (eds.), Cosmopolitanism of Nations; Giuseppe Mazzini's Writings on Democracy, Nation Building, and International Relations. Princeton: Princeton University Press. https://b-ok.cc/dl/918838/504f40.

Ruggie, G. J. (1992). Multilateralism: the anatomy of an institution. International Organization, 46(3): 561-598. https://booksc.xyz/dl/22352873/cd02cb.

Saito, H. (2011). An actor-network theory of cosmopolitanism. Sociological Theory, 29(2): 124149. https://booksc.xyz/dl/9583530/634575.

Scheid, D. E. (2011). Perpetual peace: Kant. In A. R. Bernstein (ed.), Encyclopedia of Global Justice (pp. 836-841). New York: Springer.

Schertzer, R., \& Woods, T. E. (2020). \#Nationalism: the ethnonationalist populism of Donald Trump's Twitter communication. Ethnic and Racial Studies, 44(7): 1154-1173. DOI: 10.1080/01419870.2020.1713390.

Schumaker, E. (2020, 24 April). Timeline: how coronavirus got started. ABC News. Retrieved 29 April 2020 from https://abcnews.go.com/Health/timeline-coronavirusstarted/story?id=69435165.

Serhan, Y. (2019, 25 October). A disunited kingdom falls apart; Nationalism helped drive the Brexit vote. Could it also tear Britain apart?. The Atlantic. Retrieved 16 May 2020 from https://www.theatlantic.com/international/archive/2019/10/britain-nationalism-unitedkingdom/600652/

Straehle, C. (2020). Associative solidarity, relational goods, and autonomy for refugees: what does it mean to stand in solidarity with refugees? Social Philosophy, 51(4): 526-542. DOI: $10.1111 /$ josp. 12339 .

Surak, K. (2019, 15 May). Shinzo Abe and the rise of Japanese nationalism. New Statesman. $\begin{array}{llllll}\text { Retrieved } & 16 & \text { May } & 2020 & \text { from }\end{array}$ https://www.newstatesman.com/world/asia/2019/05/shinzo-abe-and-rise-japanesenationalism 
Tabak, H. (2020). The cosmopolitan karma: coronavirus pandemic and the fate of globalisation. Political Reflection, VI. CESRAN International. http://politicalreflectionmagazine.com/wp-content/uploads/2020/04/PR_Issue23A4.pdf

Teo, T.-A. (2020). Nationalism and cosmopolitanism: a post-pandemic balance?. S. Rajaratnam School of International Studies. https://www.rsis.edu.sg/wpcontent/uploads/2020/05/C020096.pdf

The Local. (2020, 4 March). Germany bans exports of mask and gloves over coronavirus. Retrieved 17 May 2020 from https://www.thelocal.de/20200304/germany-bans-exportof-medical-protection-gear-over-coronavirus.

Tondo, L. (2020, 24 February). Salvini attacks Italy PM over coronavirus and links to rescue ship. The Guardian. Retrieved 20 May 2020 from https://www.theguardian.com/world/2020/feb/24/salvini-attacks-italy-pm-overcoronavirus-and-links-to-rescue-ship.

Triandafyllidou, A. (2020). Spaces of solidarity and spaces of exception at the times of Covid19. International Migration, 58(3): 261-263. DOI: 10.1111/imig.12719.

Turnbull, S. (2020, 3 April). 3M says Trump halting mask exports to Canada has 'significant humanitarian implications'. CTVNews. Retrieved 19 May 2020 from https://www.ctvnews.ca/politics/3m-says-trump-halting-mask-exports-to-canada-hassignificant-humanitarian-implications-1.4881032.

United States Institute of Peace. (2020, 23 March). Khamenei refuses U.S. help on COVID-19. Retrieved 3 May 2020 from https://iranprimer.usip.org/blog/2020/mar/23/khameneirefuses-us-help-covid-19.

UN News. (2020, 7 May). Migrants stranded 'all over the world' and at risk from coronavirus. Retrieved 28 May 2020 from https://news.un.org/en/story/2020/05/1063482.

Vang, S. (2020, 1 April). Trump adds to Asian-Americans' fears. The Diplomat. Retrieved 10 May 2020 from https://thediplomat.com/2020/04/trump-adds-to-asian-americans-fears/.

Wang, P., Anderson, N., Pan, Y., Poon, L., Charlton, C., Zelyas, N., Persing, D., Rhoads, D., \& Babcock, H. (2020). The SARS-CoV-2 outbreak: diagnosis, infection prevention, and public perception. Clinical Chemistry, 66(5): 644-651. DOI: 10.1093/clinchem/hvaa080.

Walt, M. S. (2020, 20 March). A world less open, prosperous, and free. Foreign Policy. Retrieved 19 May 2020 from https://foreignpolicy.com/2020/03/20/world-order-after-coroanviruspandemic/.

Web24 News. (2020, 15 March). France and Germany lift the ban on the export of medical equipment, announces Thierry Breton. Retrieved 19 May 2020 from https://www.web24.news/u/2020/03/france-and-germany-lift-the-ban-on-the-export-ofmedical-equipment-announces-thierry-breton.html.

World Economic Forum. (2020, 6 April). The coronavirus pandemic could be devastating for the world's migrants. $\quad$ Retrieved 28 May 2020 from 
https://www.weforum.org/agenda/2020/04/the-coronavirus-pandemic-could-bedevastating-for-the-worlds-refugees/.

World Food Programme. (2020). 2020 global report on food crisis. https://docs.wfp.org/api/documents/WFP0000114546/download/?_ga=2.226638932.819364690.15903337721685401963.1590333772.

World Health Organization. (2020). COVID-19: ensuring refugees and migrants are not left behind. Retrieved 25 May 2020 from http://www.euro.who.int/en/health-topics/healthdeterminants/migration-and-health/news/news/2020/4/covid-19-ensuring-refugeesand-migrants-are-not-left-behind.

Wynne, A. (2020, 6 March). Germany and France are condemned by other EU members after blocking the export of medical supplies, raising alarms among smaller countries hit by coronavirus. Daily Mail. Retrieved 19 May 2020 from https://www.dailymail.co.uk/news/article-8083527/Germany-France-condemned-EUmembers-blocking-export-medical-supplies.html.

Zolberg Institute on Migration and Mobility. (2020). Human mobility and human rights in the COVID-19 pandemic: principles of protection for migrants, refugees, and other displaced persons. https://zolberginstitute.org/covid-19/\#Human\%20Rights\%20Document 